\title{
EFFECT OF FOLIAR APPLICATION WITH AMINOTOTAL UNDER DIFFERENT RATES FROM NITROGEN FERTILIZER ON YIELD AND ITS COMPONENTS OF GIZA 86 COTTON CULTIVAR. \\ EI-Gabiery, A.E. ${ }^{*}$ and E.A.E. Mesbah** \\ * Cotton Res. Inst., Agric. Res. Center, Giza, Egypt. \\ ** Agronomy Dept., Fac. Agric., Al-Azhar Univ., Cairo, Egypt.
}

\begin{abstract}
Two field experiments were carried out at Gemmeiza Agricultural Research Station, Gharbia Governorate during two seasons (2008 and 2009) to study the effect of four aminototal concentration (i.e without, $1 \mathrm{~g} / \mathrm{L}, 2 \mathrm{~g} / \mathrm{L}$ and $3 \mathrm{~g} / \mathrm{L}$ ) under three $\mathrm{N}$ $(15,30$. and $45 \mathrm{Kg} \mathrm{N} / \mathrm{fad}$.) and their interaction on leaf chemical composition, yield and yield components of the Egyptian cotton cultivar, Giza 86. Results indicated that the differences between $\mathrm{N}$ rates for leaf $\mathrm{N}$ content, number of fruiting branches / plant, plant height, number of flowers and bolls / plant, earliness \%, boll weight, seed cotton yield per plant and per fad. were significant in the two seasons, where, boll setting $\%$ and boll shedding \% were significant in the first season only. Rate of $\mathrm{N}$ fertilizer $45 \mathrm{~kg}$ $\mathrm{N} /$ fad. Gave the highest values for leaf $\mathrm{N}$ content, number of fruiting branches per plant and plant height, where, $30 \mathrm{~kg} \mathrm{~N} / \mathrm{fad}$. Gave the highest values for leaf $\mathrm{K}$ content, number of flowers and bolls per plant, boll weight, seed cotton yield / plant and per fad., on the other hand, $15 \mathrm{~kg} \mathrm{~N} / \mathrm{fad}$ gave the best values for earliness \% in the both seasons. The differences between $45 \mathrm{~kg} \mathrm{~N} / \mathrm{fad}$ and $30 \mathrm{~kg} \mathrm{~N} / \mathrm{fad}$. were insignificant for all studied traits in the both seasons. Foliar application of aminototal gave a significant effect on leaf $\mathrm{N}$ and $\mathrm{K}$ contents, number of fruiting branches per plant, plant height, number of flowers and bolls per plant, boll weight, seed cotton yield per plant and per fad. on the other hand, earliness $\%$, boll setting and boll shedding $\%$ were insignificant in the two seasons. Foliar cotton plants with concentration of 3 or $2 \mathrm{~g} / \mathrm{L}$ from aminototal gave the highest values of most studied attributes. The differences between $2 \mathrm{~g}$ and $3 \mathrm{~g} / \mathrm{L}$ aminototal were in significant of all studied traits. The interaction between $\mathrm{N}$ rates and aminototal concentration were significant for all studied traits except earliness \% in the two seasons. Also, results show that, fertilization cotton plants with $30 \mathrm{~kg} \mathrm{~N} / \mathrm{fad}$. and sprayed with $2 \mathrm{~g} / \mathrm{L}$ aminototal increased the yield and yield components under experiment soil conditions.
\end{abstract}

Keywords: Cotton, Nitrogen fertilizers. Aminototal, clay loam.

\section{INTRODUCTION}

Attainment of maximum yield of cotton and improving its yield is greatly dependent upon appropriate use of mineral $\mathrm{N}$ rates to avoid adverse effects and losses of $\mathrm{N}$, air pollution caused by extensive use of mineral $\mathrm{N}$ fertilizer. Increasing the yield of cotton and improving has been achieved by the appropriate use of mineral $\mathrm{N}$ rate Aminototal, a plant consisting of 17 kinds of free amino acids in L-amino acids form as shown in Table 1. It improves the plant tolerance to stressed or adverse conditions i.e high temperature, drought and salinity. Some amino acids play an important role in permitting the plant to set and retain more bolls. Some amino acids play an important role in synthesis of some hormons i.e auxins. Amino acids play an 
important role in photosynthesis by increasing chlorophyll concentration. Also, amino acids act as chelating factor which help in transport and absorption of micronutrients where, El- Shazly and El- Masri (2003) found that the low $\mathrm{N}$ rate $(30 \mathrm{Kg} / \mathrm{fad}$.) significantly increased leaf $\mathrm{K}$ content and significantly decreased leaf $\mathrm{N}$ content in both seasons as compared with the medium ( $60 \mathrm{Kg} \mathrm{N} / \mathrm{fad}$.) or high $\mathrm{N}(90 \mathrm{Kg} \mathrm{N} / \mathrm{fad}$.) rates. The highest values of seed cotton yield per plant as well as per fad. were obtained from plants receiving the medium $\mathrm{N}$ rate $(60 \mathrm{Kg} \mathrm{N} /$ fad.) followed by those receiving the low $\mathrm{N}$ rate $(30 \mathrm{Kg} \mathrm{N} / \mathrm{fad}$.) without any significant differences between these two rates, while plants receiving the high $\mathrm{N}$ rate $(90 \mathrm{Kg} \mathrm{N} / \mathrm{fad}$.) produced the lowest values of these traits. However, Lichaohai et al. (1996) indicated that amino acids foliar application to cotton significantly improves boll setting rate and yield increases ranged from 14.2 to $34.6 \%$ Agboma et al. (1997), Gorham and Jokinen, (1998) and concluded that of foliar sprays of glycine betaine improved the growth of field. Grown cotton in Pakistan when $3 \mathrm{Kg} / \mathrm{ha}$ applied at time of squaring. Also, to achieve higher yield of amino acids application Kuzentsov et al. (2000) reported that mainly arginine, proline and asparagines were severely accumulated in the cell sap of cotton plants grown under water deficit to increase the resistance system under stress condition. Also, Namich (2003) found that glycine betaine dose and time of application had highly significant effects on chlorophyll, carbohydrate, phenolic compounds, total amino nitrogen in cotton leaves and significant increased in number of bolls and flowers per plant and seed cotton yield per fad.. Meek et al. (2003) indicated that spraying cotton plants with glycine betaine improved the yield and stress tolerance, also, Namich (2007) indicated that spraying cotton plants with glycine betaine with $600 \mathrm{~g} / \mathrm{fad}$. Under normal and drought conditions tended to increase physiological processes i.e., stomatal conductance, photosynthetic rate and this tended to a significant increase in growth parameters i.e., number of nodes and fruiting branches, leaf area index, dry weight per plant, root/ shout ratio and some chemical content in cotton leaves i.e., chlorophyll $A, B$ and carotein, Also, the application of glycine beanie tended to a significant increase in number of flowers and bolls per plant, boll setting and boll weight and seed cotton yield. Namich (2008) found that spraying proline solution on cotton plants seemed to increase all growth parameters and some chemical contents of leaves i.e. chlorophylls $A$ and $B$, carotein, Proline application resulted insignificant increases in nose of flowers and bolls/ plant, boll setting, boll weight and seed cotton yield / plant and also, to achieve higher yield of amino acids fertilization El- Menshawi (2008) studied effect of green stime foliar application with rates, 400, 600 and $800 \mathrm{~g} / \mathrm{fad}$., showed increased in plant height, total chlorophyll, carbohydrate, total nitrogen content in cotton leaves, number of fruiting branches, number of flowers and bolls per plant, and boll setting percentage, while, non significantly affected green stime sprayed on boll weight. Also, Ibrahim et al (2009) found that application of arginine significantly increased number of sympodia / plant, boll setting, number of bolls/ plant, boll weight and seed cotton yield/fad. 
Table 1: Aminototal Contents.

\begin{tabular}{|c|c|c|c|}
\hline $\begin{array}{c}\text { Aminototal } \\
\text { contents }\end{array}$ & Concentrate (\%) & Aminototal contents & Concentrate (\%) \\
\hline Threonine & $3.05-3.56$ & Valine & $2.8-3.1$ \\
\hline Aspartic & $3.2-3.45$ & Methionine & $0.23-0.31$ \\
\hline Serine & $3.76-4.49$ & Iso leucine & $1.26-1.7$ \\
\hline Glutamic & $7.24-9.12$ & Leucine & $1.98-2.8$ \\
\hline Proline & $2.23-3.5$ & Tyrosine & $0.48-1.02$ \\
\hline Glycine & $1.87-2.43$ & Phenylalamine & $1.03-1.78$ \\
\hline A lanine & $2.16-2.2$ & Lysine & $1.39-2.3$ \\
\hline Cystine & $1.87-2.45$ & Histidine & $0.42-0.9$ \\
\hline & & Arginine & $5.3-6.3$ \\
\hline
\end{tabular}

Thus, the objective of this study was to determine the optimum aminototal concentration without risking yield loss and to determine the optimum combination of $\mathrm{N}$ rates and aminototal concentration.

\section{MATERIALS AND METHODS}

Two field experiments were carried out at Gemmeiza Agricultural Research Station, El- Gharbia Governorate, Egypt, during the two successive seasons 2008 and 2009 to study the effect of foliar sprays of aminototal at four concentration under three rates of mineral $\mathrm{N}$ and their interaction on leaf nutrients content, boll set attributes and earliness, seed cotton yield and its components of the Egyptian cotton Giza 86 cultivar (Gossypium barbadense, L).

A split plot design with 3 replicates was used.

A- The main plots were devoted to the mineral $\mathrm{N}$ rates of :

$a_{1}$ - low rate $(15 \mathrm{Kg} \mathrm{N} / \mathrm{fad}$.)

$\mathrm{a}_{2}$ - Medium rate $(30 \mathrm{Kg} \mathrm{N} / \mathrm{fad}$.)

$\mathrm{a}_{3}$ - The recommended $\mathrm{N}$ rate $(45 \mathrm{Kg} \mathrm{N} / \mathrm{fad}$.).

B- The sub- plots contained the aminototal concentration of :

$b_{1}$ - Control (untreated), Zero.

$b_{2}$ - Low concentration (1 $\left.\mathrm{g} / \mathrm{L}\right)$.

$b_{3}$ - Medium concentration $(2 \mathrm{~g} / \mathrm{L})$.

$b_{4}$ - High concentration ( $\left.3 \mathrm{~g} / \mathrm{L}\right)$.

The treatments of aminototal were applied as foliar sprays on cotton plants during squaring stage, the commence of flowering stage (80 day from sewing) and at the top of flowering (95 day from sewing) using hand operated sprayer compressed at a low volume of 200 liter / fad. Nitrogen fertilizer at the three tested rates was applied as ammonium nitrate $(33.5 \% \mathrm{~N})$ in two equal splits after thinning (36 days after planting, two plants/ hill) and before the following irrigation. In both seasons. Phosphorus fertilizer was added at the rate of $22.5 \mathrm{Kg} \mathrm{P}_{2} \mathrm{O}_{5} / \mathrm{fad}$. as calcium superphosphate $(15.5 \%$ 
$\left.\mathrm{P}_{2} \mathrm{O}_{5}\right)$ during land preparation. Potassium fertilizer was soil added at the rate of $24 \mathrm{Kg} \mathrm{K}$ O/fad. as potassium sulphate $\left(48 \% \mathrm{~K}_{2} \mathrm{O}\right)$ in one dose with $1^{\text {st }}$ dose of nitrogen fertilizer. The plot size was $13 \mathrm{~m}^{2}$ with 5 ridges of $65 \mathrm{~cm}$ wide and $4 \mathrm{~m}$ long with hills $25 \mathrm{~cm}$ apart. Planting date was $1^{\text {st }}$ April and 30 March in 2008 and 2009 seasons, respectively. The preceding crop was Egyptian clover and corn in the first and second seasons, respectively. fields.

All other cultural practices were followed as recommended in cotton

\section{Soil analysis :}

Soil analysis for the two seasons was carried out according to Jackson (1973). The results of analysis is shown in Table 2.

Table 2: Analysis of the experimental soil :

\begin{tabular}{|c|c|c|}
\hline Properties & $\mathbf{2 0 0 8}$ & $\mathbf{2 0 0 9}$ \\
\hline $\mathrm{pH}$ & 7.6 & 7.6 \\
\hline Texture & Clay loam & Clay loam \\
\hline Ec $\left(\mathrm{mmohs} / \mathrm{cm} / 25^{\circ} \mathrm{c}\right)$ & 1.2 & 1.1 \\
\hline Available $\mathrm{N}(\mathrm{ppm})$ & 17.5 & 25 \\
\hline Available $\mathrm{P}(\mathrm{ppm})$ & 16.5 & 13 \\
\hline Available $\mathrm{K}(\mathrm{ppm})$ & 362 & 317.5 \\
\hline $\mathrm{Ca} \mathrm{CO}_{3} \%$ & 1.2 & 1.9 \\
\hline
\end{tabular}

\section{Parameters studied:}

After 95, days from planting sample of 10 leaves was taken from the upper $4^{\text {th }}$ leaf on the main stem from each sub plot for the determine.

1- Nitrogen content in leaves (\%) A.O.A.C. (1975).

2- Potassium content in leaves (\%).

Total $\mathrm{N}$ was determine with using Micro-KJeldahl method as described by Allen (1953), and total K content according to Chapman and Pratt (1961).

At harvest, plants of five guarded hills were taken at random from the second ridge of each sub plot to determine:

3- Plant height $(\mathrm{cm})$.

4- Number of fruiting branches/plant.

5- Number of total flowers / plant.

6- Number of total bolls /plant.

7- Boll weight $(\mathrm{g})$.

8- Boll setting (\%).

9- Boll shedding (\%).

10- Earliness (\%).

11- Seed cotton yield/plant $(\mathrm{g})$

12- Seed cotton yield/fad. (Kentar). Was calculated from the yield of the total ridges of each sub plot.
Boll setting $\%=$
Number of total bolls/ plant
Number of total flowers/plant 


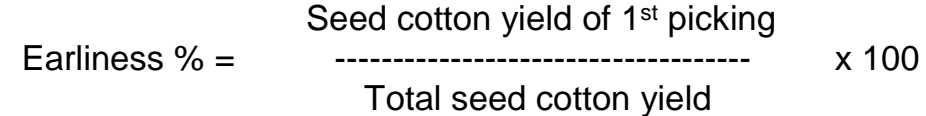

\section{Statistical analysis}

Finally, all obtained data were subjected to analysis of variance and treatment means were compared by L.S.D. test at the $5 \%$ level of probability in the tow experimented season according to Gomez and Gomez 1983

\section{RESULTS AND DISCUSSION}

\section{A- Effect of mineral $\mathrm{N}$ rates:}

\section{Leaf $\mathrm{N}$ and $\mathrm{K}$ contents :}

Results in Table (3) show that different $\mathrm{N}$ rates gave a significant effect on leaf $\mathrm{N}$ and $\mathrm{K}$ contents in both seasons. With regard to leaf $\mathrm{N}$ content, the highest values were obtained from the high $N$ rate $(45 \mathrm{Kg} \mathrm{N} / \mathrm{fad}$.) followed by the medium rate $(30 \mathrm{Kg} \mathrm{N} / \mathrm{fad}$.), while the lowest values were obtained from the low $\mathrm{N}$ rate $(15 \mathrm{Kg} \mathrm{N} / \mathrm{fad}$.).

Table 3: Effect of Nitrogen rates and aminototal concentration on $\mathrm{N}$ and $\mathrm{K} \%$ after 95 days from sowing, number of fruiting branches/ plant and plant height at harvest in 2008 and 2009 seasons.

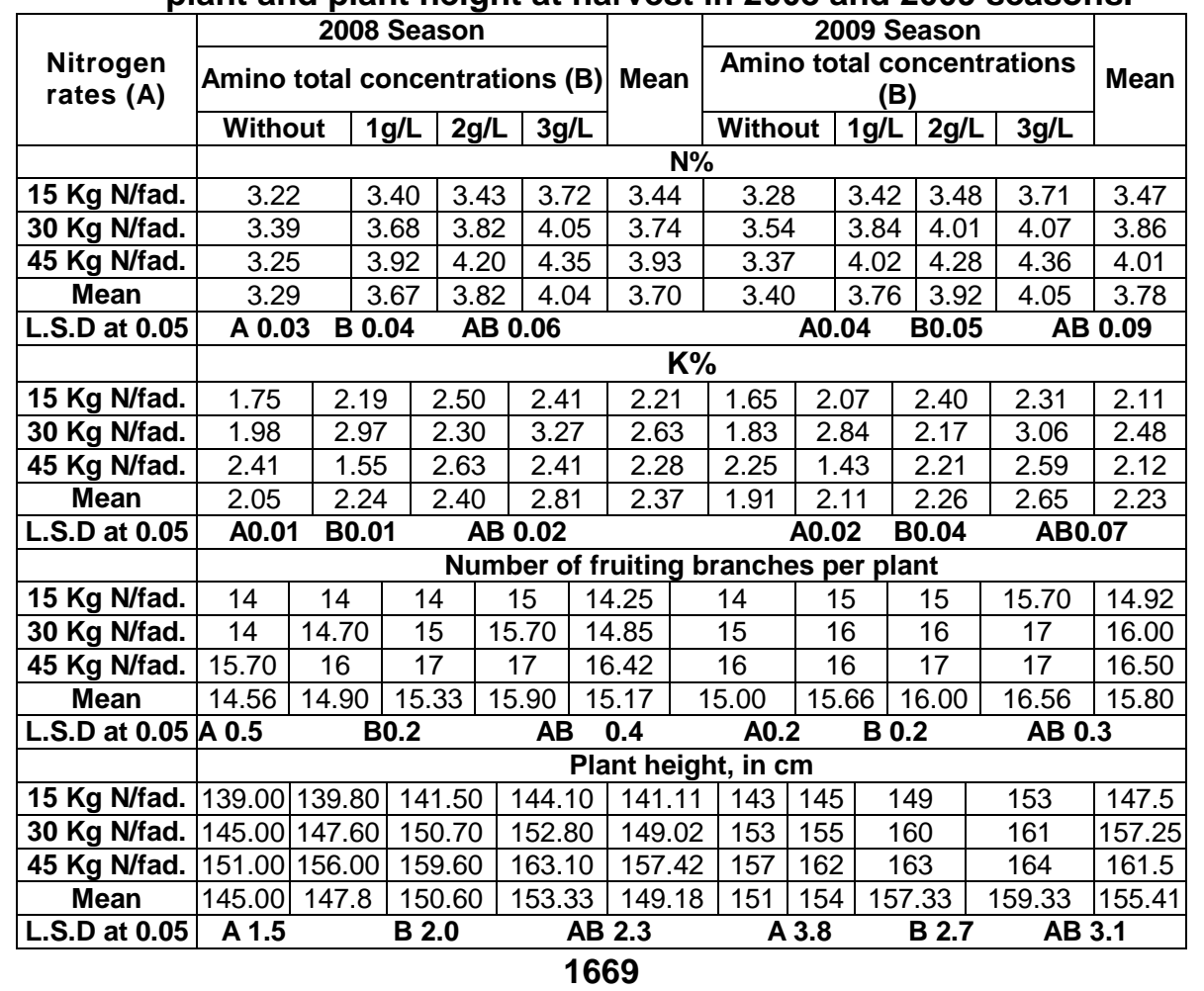


From the same Table it could be noticed that the concentration of leaf $\mathrm{N}$ in the second season is higher than the first season. This difference may be due to that soil of the experimental site in the second season had higher $\mathrm{N}$ content than in the first season (17.5 and $25 \mathrm{ppm}$ ) as shown in Table (2). In this concern, Hamissa et al (2000), El- Shazly and El- Masri (2003) and Ghodpage et al (2009) found that the low $\mathrm{N}$ rates significantly decreased leaf $\mathrm{N}$ content.

With regard to leaf $\mathrm{K}$ content, the highest values were obtained from the medium rates of $\mathrm{N}(30 \mathrm{Kg} / \mathrm{fad}$.) followed by the high $\mathrm{N}$ rate $(45 \mathrm{Kg} \mathrm{N} / \mathrm{fad}$.), while the lowest values were obtained from the low $N$ rate ( $15 \mathrm{Kg} \mathrm{N} / \mathrm{fad}$.). In both seasons. Leaf $\mathrm{K}$ content significantly decreased by increasing $\mathrm{N}$ rate from 30 to $45 \mathrm{Kg} \mathrm{N} /$ fad. In this concern, El- Shazly and El- Masri (2003) found that low rate of $\mathrm{N}$ significantly increased leaf $\mathrm{K}$ content.

Results in Table 3 show that $\mathrm{N}$ rates exhibited significant differences in plant height and number of fruiting branches/ plant in both seasons, in favor of high $\mathrm{N}$ rate. This increase may be attributed to the increase in the meristematic activity as well as production of auxin which encourage cell division and elongation. In this concern, El- Sayed and El- Menshawi (2005) found that increasing $\mathrm{N}$ fertilizer rate up to $80 \mathrm{Kg} /$ fad. significantly increased final plant height and number of sympodia / plant, Prasad and Siddique (2004) and Khan et al. (2005) found that plant height increased with increasing rates of $\mathrm{N}$.

Boll set attributes and earliness :

From Results in Table 4 it is clear that rates of $\mathrm{N}$ significantly affected numbers of total flowers and total bolls per plant in both seasons and boll setting and shedding percentages in the first season only. The medium $\mathrm{N}$ rate (30 Kg N/fad.) had the highest values of numbers of total flowers and total bolls per plant followed by the high $\mathrm{N}$ rate $(45 \mathrm{Kg} \mathrm{N} /$ fad.), while the low $\mathrm{N}$ rate (15 Kg N/fad.) gave the lowest numbers. This result may be due to the increase in number of fruiting branches / plant due to the medium and high levels as compared with the low $\mathrm{N}$ rate which leads to bear more bolls. Also, the medium rate significantly increased boll setting \% and decreased boll shedding $\%$ as compared with the high $\mathrm{N}$ rate in the first season, while the increase in the second season was insignificant.

Rates of $\mathrm{N}$ had a significant effect on earliness \% in both, seasons (Table 5), in favor of the low mineral $\mathrm{N}$ rate. However, the lowest earliness percentage was produced from the high $\mathrm{N}$ rate. In this regard, El- Shazly and El- Masri (2003) found that number of fruiting positions/ plant, boll shedding $\%$ and earliness \% exhibited significant differences due to the variation in $\mathrm{N}$ rates in both seasons, the high $\mathrm{N}$ rate $(90 \mathrm{Kg} \mathrm{N} / \mathrm{fad}$.) significantly increased the number of fruiting positions per plant and shedding \% and significantly decreased boll setting and earliness percentage in both seasons as compared with the low $\mathrm{N}$ rate $(30 \mathrm{Kg} \mathrm{N} / \mathrm{fad}$.) or the medium $\mathrm{N}$ rate $(60 \mathrm{Kg}$ $\mathrm{N} / \mathrm{fad}$.) and Prasad and Siddique (2004) found that earliness showed a declining trend with an increase in $\mathrm{N}$ rate. 
Table 4: Effect of nitrogen rates and aminototal concentration on number of flowers per plant, number of bolls per plant, boll setting (\%) and boll shedding (\%)in 2008 and 2009 seasons.

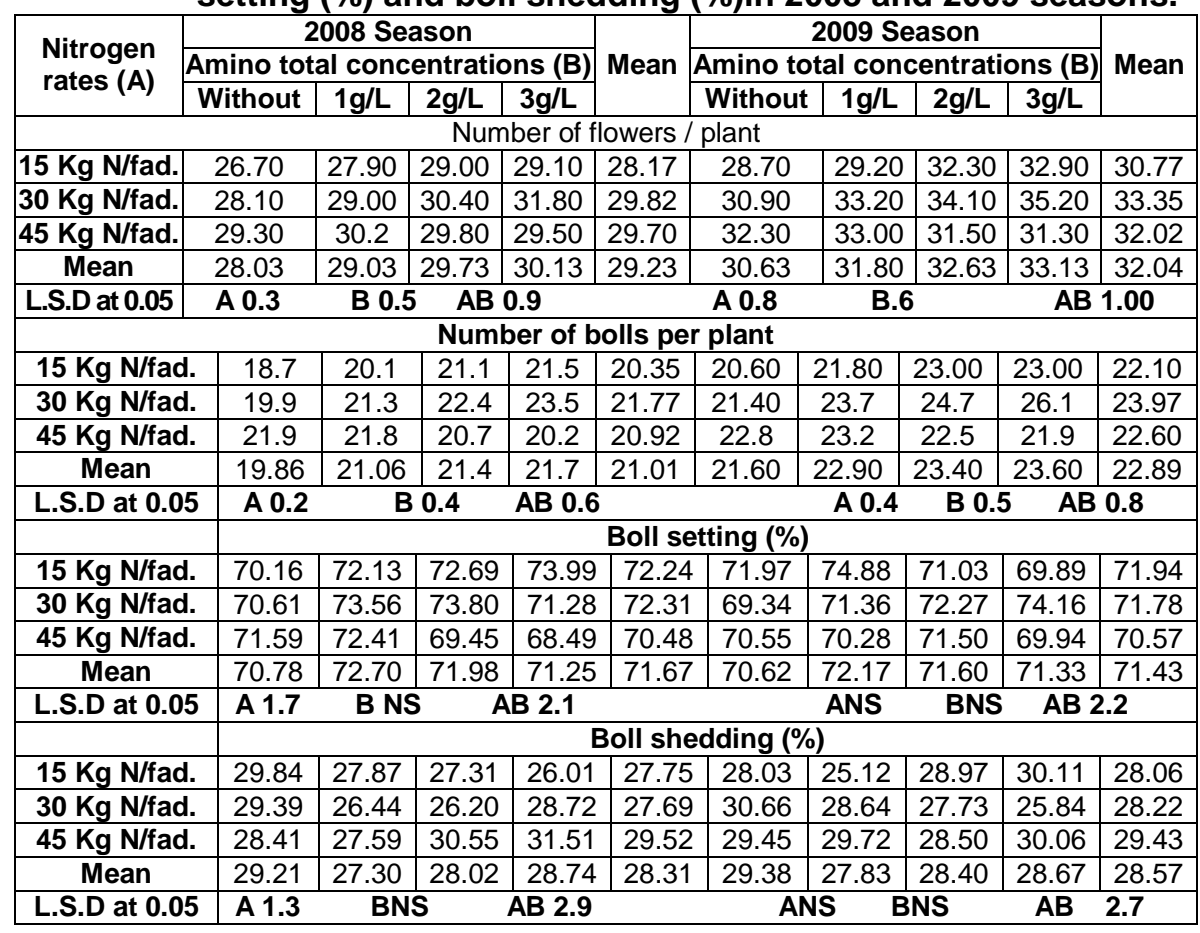

\section{Seed cotton yield and its components :}

Rates of $\mathrm{N}$ application had a significant effect on boll weight, seed cotton yield per plant as well as per fad. in both seasons (Table 5). The increase of the yield / plant in the medium $\mathrm{N}$ rate $(30 \mathrm{Kg} \mathrm{N} / \mathrm{fad})$. was primarily caused by increased boll weight and number of open bolls/plant and the increase in number of open bolls / plant may be due to the increase in number of flowers/ plant and the ability of plants o retain more bolls by decreasing shedding percentage. The significant increase in boll weight due to the medium $\mathrm{N}$ rate may be due to that this rate had a higher leaf $\mathrm{K}$ content as compared with the low or high $\mathrm{N}$ rates and $\mathrm{K}$ plays an important role in many of the vital physiological processes in the plant, such as transpiration, translocation of sugars and starch, protein formation and osmotic regulation and this reflect on boll weight. The medium $\mathrm{N}$ rate significant increased seed cotton yield per fad. by 1.05 and 0.65 kentar in the first season and by 1.40 and 0.73 kentar in the second season as compared with the low and high $\mathrm{N}$ rates, respectively. The highest yield of plots which receiving the medium $\mathrm{N}$ rate $(30 \mathrm{Kg}$ $\mathrm{N} /$ fad.) is mainly due to increased boll retention which leads to increase number of open bolls/plant increased boll weight due to the positive effects of leaf $\mathrm{N}$ and $\mathrm{K}$ 
contents. In this concern El- Shazly and El- Masri (2003) found that number of open bolls and seed cotton yield per plant and per fad. Exhibited significant differences due to the variation in $\mathrm{N}$ rates in both seasons, in favor of the medium $\mathrm{N}$ rate, Prasad and Siddique (2004) found that number of bolls/plant and boll weight significantly increased with an increase in $\mathrm{N}$ rate. The yield of seed cotton significantly increased with an increase in $\mathrm{N}$ rate up to $80 \mathrm{Kg} \mathrm{N} / \mathrm{ha}$.

Table 5: Effect of Nitrogen rates and aminototal concentration on Earliness, Boll weight, Seed cotton yield per plant and Seed cotton yield in 2008 and 2009 seasons.

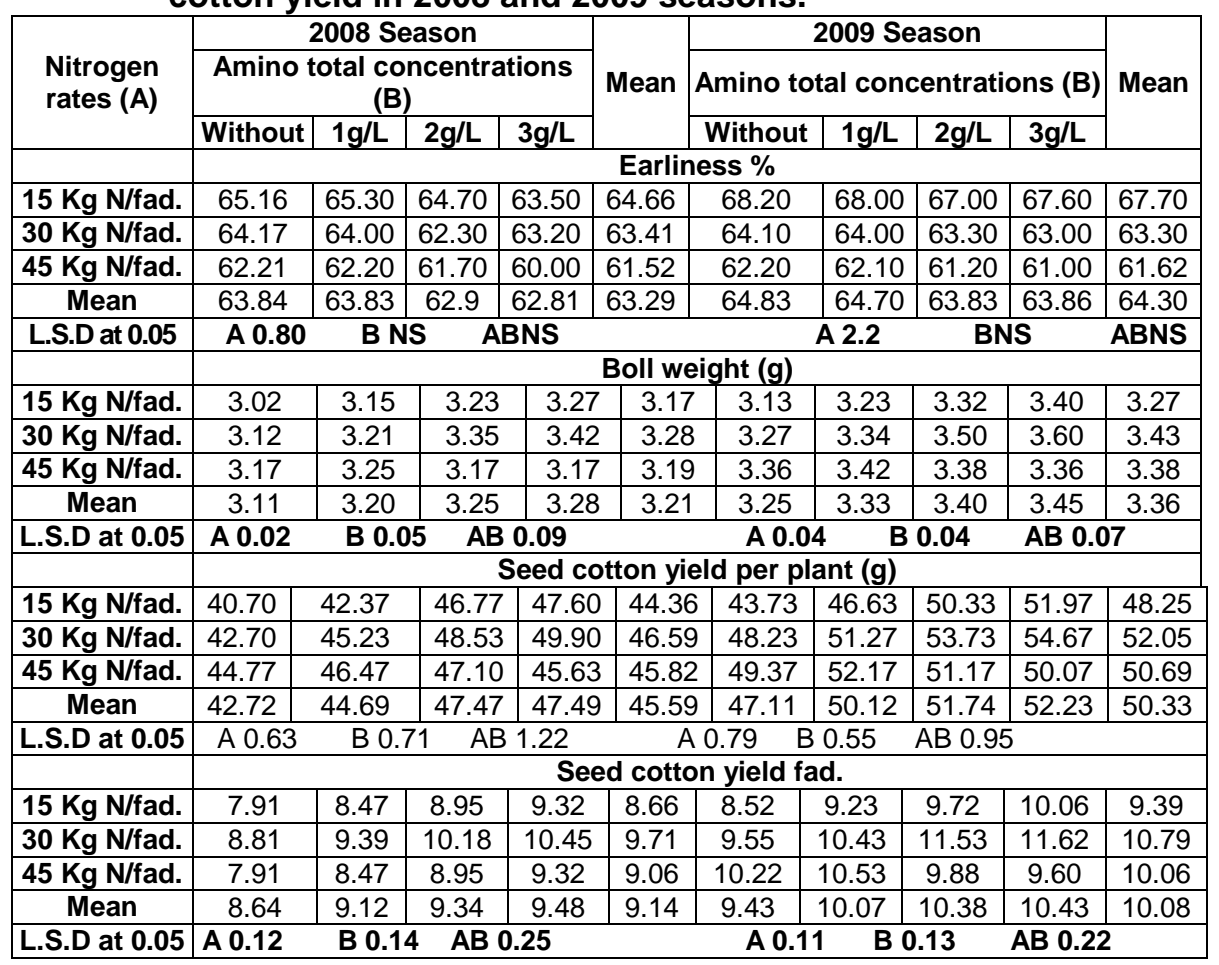

\section{B- Effect of foliar application of aminototal concentration Leaf $\mathrm{N}$ and $\mathrm{K}$ contents :}

Results in Table 3 show that foliar application of aminototal gave a significant effect on leaf $\mathrm{N}$ and $\mathrm{K}$ contents in both seasons. The maximum value for leaf $\mathrm{N}$ and $\mathrm{K}$ contents were obtained from $3 \mathrm{~g} / \mathrm{L}$. concentration followed by $2 \mathrm{~g} / \mathrm{L}$. and $1 \mathrm{~g} / \mathrm{L}$.. The positive effect of the high concentration of aminototal on leaf $\mathrm{N}$ and $\mathrm{K}$ may be due to proline may be a good storage of $\mathrm{N}$ because of its metabolic proximity having already conversion to glutamic acid, which considered a key compound in $\mathrm{N}$ metabolism. Furthermore, the conversation of proline to glutamic acid, twg equivalents of NADPH are produced making proline already available source of energy and reducing power (Stewart and Lee, 1974). Proline plays role as an osomolytes for 
osmotic adjustment, buffering cellular redox potential (under stress conditions) it also may cause cytoplasmic acidosis and maintaining appropriate NADP+/NADPH ratios compatible with metabolism. In another study. Namich (2003) found that glycine betaine had highly significant effect on nitrogen in cotton leaves. In this concern, Namich (2008) found that spraying proline solution on cotton plants had a significant increase in ions of $\mathrm{K}^{+}$in cotton leaves.

Aminototal gave a significant effect on plant height and number of fruiting branches / plant in both seasons (Table 3), the tallest plants and the highest number of fruiting branches/plant were recorded by the high concentration of aminototal ( $3 \mathrm{~g} / \mathrm{L}$.), while the shortest plants and the lowest number of fruiting branches/ plant were produced from untreated plots (control). The increase in plant height due to the high concentration of aminototal may be due to the increase in auxins in case of aminototal treated plants which have a role in cell division and cell expansion, also, this increase in plant height may be due to that amino acids act as chelating factor which help in transport and absorption of micronutrients. i.e. $\mathrm{Zn}$ which involved in the synthesis of indole acetic acid which play an important role in plant growth. $\mathrm{N}$ plays an important role in increasing the meristematic activity as well as production of auxin which encourage cell division and elongation. In this concern, Namich (2007) reported that proline would be a good source of energy and $\mathrm{N}$ for the plant under drought conditions. Also, she found that spraying proline solution on cotton plants under normal and salinity conditions had a significant increase on plant height and number of fruiting branches per plant as compared with control and she attributed this increase to a corresponding increase in photosynthesis pigments, photosynthesis rate and carbohydrate content. In another study, Namich (2008) found that foliar application of glycine betaine had significant increase in plant length and number of fruiting branches per plant as compared with the control in both seasons and Ibrahim et al. (2009) found that plant height was significantly increased by arginine treatments in both seasons. The positive effect of arginine on vegetative growth of cotton plants could be attributed to the high concentration of endogenous hormones IAA, GA and cytokinins in treated plants which appear to form a sink mobilizing the different nutrients which are involved in building new tissues in treated plants.

Boll set attributes and earliness :

Results in Table 4 show significant differences among aminototal concentrations for numbers of flowers and bolls per plant in both seasons. The high concentration $(3 \mathrm{~g} / \mathrm{L})$ of aminototal had the highest values of these two traits followed by the medium concentration $(2 \mathrm{~g} / \mathrm{L})$ without any significant difference between these two treatments, while untreated plants (control) gave the lowest values, this trend was true in both seasons. This increase in numbers of total flowers and total bolls/ plant due to the high concentration of aminototal is mainly due to the increase in number of fruiting branches/plant 
(Table 3) which bear more flowers and consequently more bolls. Also, results in the same Table and Table (5) show that aminototal concentrations did not affect boll setting and shedding percentages and earliness percentages in both seasons. In this concern, Namich (2007) found that applying proline or glycine under normal and different concentrations of salinity tended to increase the numbers of flowers and bolls/ plant and boll setting percentage in another study, Namich (2008) found that applying glycine betaine under normal and water stress conditions tended to increase the numbers of flowers and bolls/ plant and boll setting percentage and she attributed this effect to the improving effects of glycine betaine on the physiological functions i.e., stomatal conductance and photosynthesis rate as well as increasing in chemical contents of cotton leaves and Ibrahim et al (2009) found that boll setting percentage of cotton plants was significantly increased under the effect of arginine.

Seed cotton yield / fad. and its components :

Aminototal significant effect on boll weight, seed cotton yield per plant as well as per fad. in both seasons (Table 5). The highest values of these traits were obtained from plants receiving the high concentration of aminototal $(3 \mathrm{~g} / \mathrm{L})$ followed by the medium concentration $(2 \mathrm{~g} / \mathrm{L})$ without any significant differences between these two concentration, while the lowest values were obtained from the low concentration $(1 \mathrm{~g} / \mathrm{L})$ and untreated plants. The increase number of open bolls/ plant may be due to that the increase in aminototal concentration led to increase in number of fruiting branches/ plant (Table 3) and consequently led to higher numbers of total flowers and bolls / plants (Table 4). The increase boll weight in plants which receiving the high or medium concentrations of aminototal was primarily caused by increased leaf $\mathrm{N}$ and $\mathrm{K}$ contents (Tables 3). $\mathrm{N}$ plays an important role in photosynthetic rate and accumulation of carbohydrates. $\mathrm{K}$ plays an important role in many of the vital physiological processes in the plant, such as translocation of sugars and starch. This leads to increase boll weight. The increase in seed cotton yield/ plant is primarily due to the increase in number and weight of open bolls due to the high concentration of aminototal. The high concentration of aminototal increased seed cotton yield/fad. by $9.72,3.95$ and $1.5 \%$ in the first season and by $10.60,3.57$ and $0.48 \%$ in the second season above that of untreated plots, the low concentration and the medium concentration, respectively. The increase in seed cotton/fad. in case of high rate or medium rate may be due to the following : increase number of fruiting branches/ plant/ increased number of open bolls/ plant, boll weight and seed cotton yield / plant. The positive effects due to aminototal treatments can be attributed to that : amino acids in this compound play an important role in synthesis of some hormones i.e. auxins and acts as chelating factor which help in transport and absorption of micronutrients. Also, these amino acids play an important role in protein synthesis and in photosynthesis by increasing chlorophyll concentration and consequently led to best growth which reflected on best yield. In this concern, Namich (2007) found that foliar application of proline resulted in significant increase in yield and yield components in two years, except of boll weight in one season. In another study, Namich (2008) 
found that foliar application of glycine betaine had a significant increase in yield and yield components and she reported that this effect is mainly due to improving effects of glycine betaine on the physiological functions i.e.., stomatal conductance and photosynthesis rate as well as increasing in chemical contents of cotton leaves. and Ibrahim et al. (2009) found that amino acid arginine significantly increased number of open bolls, boll weight, seed cotton yield per plant as well as per fad..

\section{C- Effect of the interaction :}

\section{Leaf $\mathrm{N}$ and $\mathrm{K}$ contents :}

The interaction between $\mathrm{N}$ rates and aminototal concentration gave significant effect on leaf $\mathrm{N}$ and $\mathrm{K}$ contents in both seasons (Table 3). The highest values of leaf $\mathrm{N}$ content ware produced from the high $\mathrm{N}$ rates when conjugated with the high concentration of aminototal $(3 \mathrm{~g} / \mathrm{L})$, while the lowest values were obtained from the low $\mathrm{N}$ rates when using alone. With regard to leaf $\mathrm{K}$ content, the highest values of this trait were produced from applying the medium $\mathrm{N}$ rate $(30 \mathrm{Kg} \mathrm{N} / \mathrm{fad}$.) when conjugated with the high concentration of aminototal $(3 \mathrm{~g} / \mathrm{L})$, while the lowest values were obtained from applying the low mineral $\mathrm{N}(15 \mathrm{Kg} \mathrm{N} /$ fad.) alone without aminototal application.

Table 3 show that the interaction between $\mathrm{N}$ rate and aminototal concentration gave insignificant effect on plant height at harvest in both seasons, but it gave significant effect on number of fruiting branches / plant in both seasons, where the highest values of this trait was produced from applying $45 \mathrm{KgN} / \mathrm{fad}$. along with aminototal concentration and the lowest values were obtained from the low $\mathrm{N}$ rate when combined with zero or the low or the medium concentration of aminototal.

\section{Boll set attributes and earliness:}

The interaction between $\mathrm{N}$ rates and aminototal concentrations significantly affected numbers of total flowers and number bolls/ plant, boll setting and shedding percentages in both seasons (Table 4), with applying 30 $\mathrm{Kg} \mathrm{N} / \mathrm{fad}$. along with $2 \mathrm{~g} / \mathrm{L}$ or $3 \mathrm{~g} / \mathrm{L}$ of aminototal with regard to the number of total flowers and bolls set/plant, while the lowest numbers were obtained from applying $15 \mathrm{Kg} \mathrm{N} / \mathrm{fad}$. alone without aminototal application. Concerning boll setting and shedding percentages, in the first season, the highest setting percentages and the lowest shedding percentages were obtained from applying $15 \mathrm{Kg} \mathrm{N} / \mathrm{fad}$. along with $3 \mathrm{~g} / \mathrm{L}$ aminototal and from applying $30 \mathrm{Kg}$ $\mathrm{N} / \mathrm{fad}$. along with $1 \mathrm{~g} / \mathrm{L}$ or $2 \mathrm{~g} / \mathrm{L}$ of aminototal. However, in the second season, the highest setting percentages and the lowest shedding percentages were obtained from applying $15 \mathrm{Kg} \mathrm{N} / \mathrm{fad}$. along with $1 \mathrm{~g} / \mathrm{L}$ aminototal and from applying $30 \mathrm{Kg} \mathrm{N} / \mathrm{fad}$. along with $3 \mathrm{~g} / \mathrm{L}$ aminototal, this result could be explained in view of the following points :

The data in Table 5 show that the interaction between $\mathrm{N}$ rates and aminototal concentrations gave insignificant effect on earliness percentage in both seasons. 


\section{Seed cotton yield/fad. and its components :}

From Table (5) obtained that with increased the aminototal concentrations from $1 \mathrm{~g}$ to $3 \mathrm{~g} / \mathrm{L}$ increasing boll weight traits under same the rate from the nitrogen, also, with increased the nitrogen rate from 15 to $45 \mathrm{~kg}$ $\mathrm{N} / \mathrm{fad}$. Increasing boll weight traits under same the rate from the aminototal. The interaction between $\mathrm{N}$ rates and aminototal concentration gave a significant effect on boll weight, seed cotton yield per plant as well as per fad. in both seasons (Table 5), in favor of applying $30 \mathrm{Kg} \mathrm{N} /$ fad. when conjugated with $3 \mathrm{~g} / \mathrm{L}$ aminototal or $2 \mathrm{~g} / \mathrm{L}$ aminototal, respectively. While, the lowest values of these traits were obtained from applying $15 \mathrm{Kg} \mathrm{N} / \mathrm{fad}$. alone without aminototal application in both seasons.

A reference to Table 3 indicate that leaf $\mathrm{N}$ and $\mathrm{K}$ contents were significantly increased due to applying $30 \mathrm{Kg} \mathrm{N} / \mathrm{fad}$. when conjugated with 3 $\mathrm{g} / \mathrm{L}$ aminototal in both seasons as compared with the other treatments and thus improved flow of assimilates and accumulate more dry weight in fruiting organs, also, amino acids in aminototal compound enhance photosynthesis and hence more photosynthesis seemed to be more available for cotton growth and development. The positive effect of foliar feeding with aminototal when conjugated with mineral $\mathrm{N}$ on seed cotton yield and its components is mainly attributed to that :

This interaction significantly increased boll setting percentage and numbers of total flowers and bolls set/ plant and this reflected on increasing number of open bolls per plant.

\section{REFERENCES}

Agboma, M.; Jones, M.G.K., Pettonen-Sainio, P.; Rita, H. and Peha, E. (1997): Exogenous glycine betaine enhances grain yield of maize, sorghum and wheat grown under two supplementary watering regimes. J. Agron. and Crop Sci., 178 : 29-37.

Allen, O.N. (1953). Experiments in soil bacteriology. $1^{\text {st }}$ Ed. Burgess. Publ. Co. U.S.A.

A.O.A.C. (1975) : Official Methods of Analysis of official agricultural chemists $12^{\text {th }}$ Ed. Washington D.C.

A.S.T.M. (1975) : American society for testing and materials standard on textile materials (D 1448-59 and D 1445-67). The Society, Washington, Philadelphia, U.S.A.

Chapman, H.D. and Pratt, P.F. (1961) : Methods of analysis for soil, plants and waters, Univ. California, Division Agric. Sci.

El- Menshawi, M.E. (2008) : Effects of different doses of "Green stim" and time of spray application on yield of cotton under salinity conditions. J. Agric. Sci. Mansoura Univ., 33 (9): 6313-6322.

El- Sayed, E.A. and El- Menshawi, M. (2005) : Response of the promising hybrid cotton Giza 89 and 86 to hill spacing and nitrogen fertilizer level. J. Agric. Res. Tanta Univ., 31 (436-456. 
El- Shazly, W.M.O. and El- Masri, M.F. (2003) : Response of cotton cultivar (Giza 89) to mineral nitrogen fertilization and growth retardant. Minufiya J. Agric. Res., 28 (3) : 821-856.

Ghodpage, R.M.; Balpande, S.S. : Harale, M.A. and Mandle, M.G. (2009): Effect of a mrutpani and biofertilizer with fertilizer and vermicompost on microbiota and yield of rainfed cotton. J of soils and crops, 19 (2) : 343346.

Gomez, K.A. and Gomez, A.A. (1983) : Statistical procedures for Agricultural Research $2^{\text {nd }}$. Ed. Johan wiley U.S.A.

Gorham, J. and Jokinen (1998) : Glycine betaine treatment improves cotton yield in field trials in Pakistan. P. 329. World cotton conf. II, Athens, Greece, in press.

Hamissa, A.M.; Ziadah, K.A. and El. Masri, M.F. (2000) : Response of cotton to biofertilizer and nitrogen fertilization. Minufiya J. Agric. Res., 25 (2) : 371-388.

Ibrahim, M.E.; Bekheta, M.A.; El- Moursi, A. and Gaafar, A.N. (2009): Effect of Arginine, prohexadione-ca, some macro and micronutrients on growth, yield and fiber quality of cotton plants. World J. of Agric. Sci., 5 (5) : 863-870.

Jackson, M.L. (1973) : Soil chemical analysis. Prentice Hall of Indian Private Limited. New Delhi.

Khan, K.; Mahmood, Z.; Soomro. R.A. and Muhammad, I. (2005) : Effect of different levels of nitrogen on cotton yield and its components under climatic condition. Indus cottons, 2 (3) : 241-244.

Kuznetsov, V.V.; Rakitin, V.YU. N. G.; Sadomov and Dam, D.V. (2000): Do Polyamines participate in the long- translocation of stress signals in plant ? Russian J. of plant physiol. Academic publishing company "Nauka/interperiodica" Mosco, Russia, 49 (1) : 120-130.

Lichaohai; Chunxi X.U.; and Chengpihua (1996) : A study on the yield increasing effect of multiple trace element fertilizer containing chelated amino acids applied to cotton. China cottons. 23 (9) : 12-13.

Meek, C.; Oosterhis, D. and Gorham, J. (2003) : Does foliar applied glycine betaine effect endogenous betaine levels and yield in cotton on line. Crop Management doi. 10-1904/CM- 2003-0804-02-RS.

Namich, Alia .A.M. (2003): Effect of glycine betaine on growth, yield, yield components and some chemical constituents of cotton plant of Giza 80. Egypt. J. Appl. Sci., 18 (1) : 91-101.

Namich, Alia .A.M. (2007) : Response of cotton cultivar Giza 80 to application of glycine betaine under drought conditions. Minufiya J. Agric. Res., 32 (6) : 1637-1651.

Namich, Alia .A.M. (2008) : Effect of foliar application of proline on growth, chemical constituents and yield components of salt stressed cotton plant. Minufiya J. Agric. Res., 33 (2) : 373-386. 


\section{El-Gabiery, A.E. and E.A.E. Mesbah}

Prasad, M. and Siddique, M.R.B. (2004) : Effect of nitrogen and mepiquat chloride on yield and quality of upland cotton (Gossypium hirsutum, L.) Indian J. of Agric. Sci., 74 (10) : 560-562.

Stewart, G.R. and Lee. J.A. (1974) : The role of proline accumulation in halophytes plants, 120: 279-289.

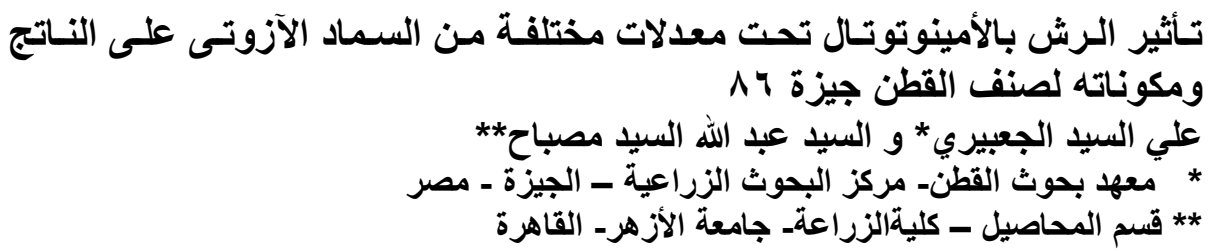

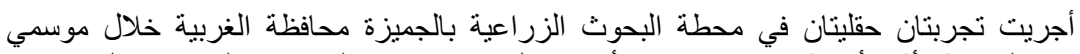

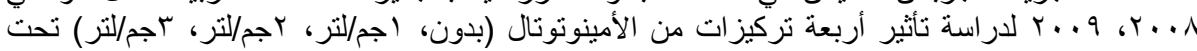

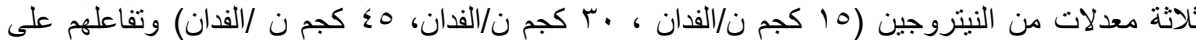

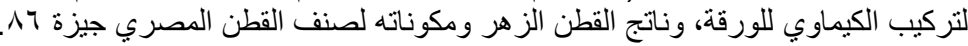

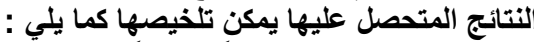

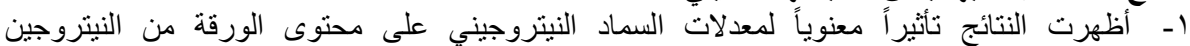

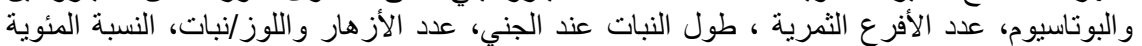

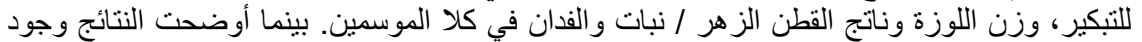

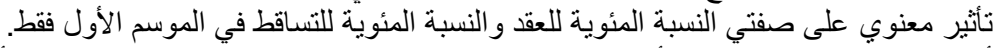

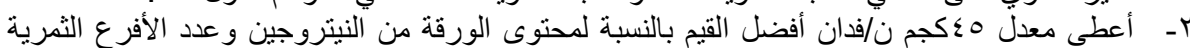

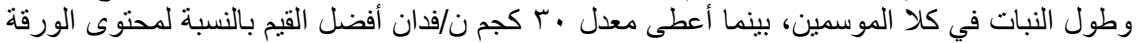

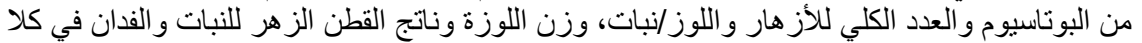

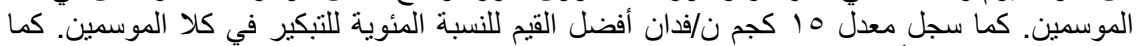

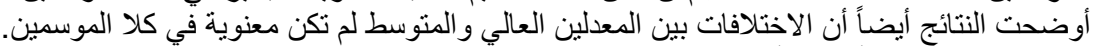

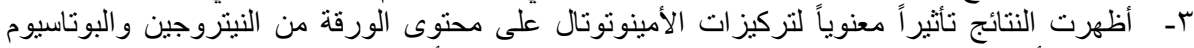

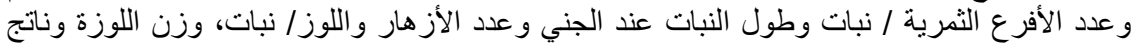

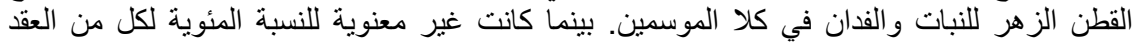
و التساقط و التبكير في كلا الموسمين.

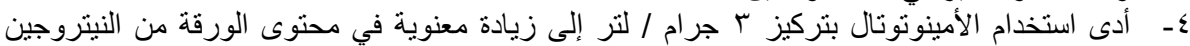

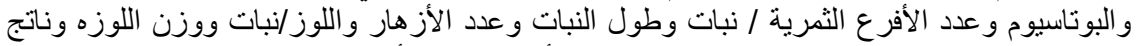

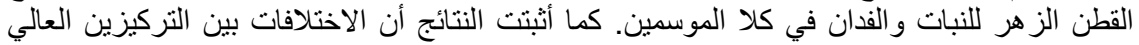
و المتوسط لم تكن معنوية في كلا الموسمين.

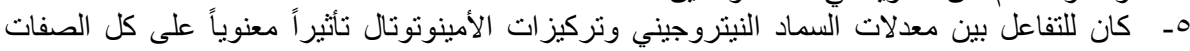
المدروسة ماعدا النسبة المئوية للتبكير في كلا الموسمين.

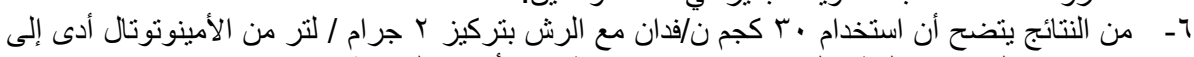
زيادة ناتج الفدان من القطن الزهر ومكوناته تحت ظروف النف أرض التجرية.

كلية الزراعة - جامعة المنصورة

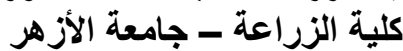

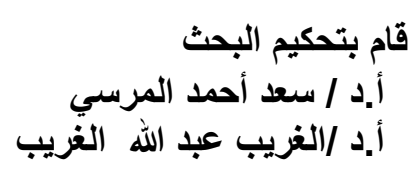

